\title{
Vegetation structure and distribution characteristics of Symplocos prunifolia, a rare evergreen broad-leaved tree in Korea
}

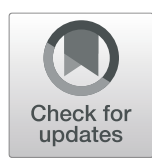

\author{
Kim Yangji, Song Kukman, Yim Eunyoung, Seo Yeonok, Choi Hyungsoon and Choi Byoungki* (D)
}

\begin{abstract}
Background: In Korea, Symplocos prunifolia Siebold. \& Zucc. is only found on Jeju Island. Conservation of the species is difficult because little is known about its distribution and natural habitat. The lack of research and survey data on the characteristics of native vegetation and distribution of this species means that there is insufficient information to guide the management and conservation of this species and related vegetation. Therefore, this study aims to identify the distribution and vegetation associated with S. prunifolia.

Results: As a result of field investigations, it was confirmed that the native S. prunifolia communities were distributed in 4 areas located on the southern side of Mt. Halla and within the evergreen broad-leaved forest zones. Furthermore, these evergreen broad-leaved forest zones are themselves located in the warm temperate zone which are distributed along the valley sides at elevations between 318 and $461 \mathrm{~m}$. S. prunifolia was only found on the south side of Mt. Halla, and mainly on south-facing slopes; however, small communities were found to be growing on northwest-facing slopes. It has been confirmed that S. prunifolia trees are rare but an important constituent species in the evergreen broad-leaved forest of Jeju. The mean importance percentage of S. prunifolia community was 48.84 for Castanopsis sieboldii, 17.79 for Quercus acuta, and 12.12 for Pinus thunbergii; S. prunifolia was the ninth most important species (2.6).

(Continued on next page)
\end{abstract}

\footnotetext{
* Correspondence: vegetation01@korea.kr

Warm Temperate and Subtropical Forest Research Center, National Institute of Forest Science, 22 Donnaeko Rd. Seogwiposi, Jeju, Special Self-Governing Province 63582, Republic of Korea
}

(c) The Author(s). 2020 Open Access This article is licensed under a Creative Commons Attribution 4.0 International License, which permits use, sharing, adaptation, distribution and reproduction in any medium or format, as long as you give appropriate credit to the original author(s) and the source, provide a link to the Creative Commons licence, and indicate if changes were made. The images or other third party material in this article are included in the article's Creative Commons licence, unless indicated otherwise in a credit line to the material. If material is not included in the article's Creative Commons licence and your intended use is not permitted by statutory regulation or exceeds the permitted use, you will need to obtain permission directly from the copyright holder. To view a copy of this licence, visit http://creativecommons.org/licenses/by/4.0/. 


\begin{abstract}
(Continued from previous page)
Conclusions: S. prunifolia can be found growing along the natural streams of Jeju, where there is little anthropogenic influence and where the streams have caused soil disturbance through natural processes of erosion and deposition of sediments. Currently, the native area of S. prunifolia is about $3300 \mathrm{~m}^{2}$, which contains a confirmed population of 180 individual plants. As a result of these low population sizes, it places it in the category of an extremely endangered plant in Korea. In some native sites, the canopy of evergreen broad-leaved forest formed, but the frequency and coverage of species were not high. Negative factors that contributed to the low distribution of this species were factors such as lacking in shade tolerance, low fruiting rates, small native areas, and special habitats as well as requiring adequate stream disturbance. Presently, due to changes in climate, it is unclear whether this species will see an increase in its population and habitat area or whether it will remain as an endangered species within Korea. What is clear, however, is that the preservation of the present native habitats and population is extremely important if the population is to be maintained and expanded. It is also meaningful in terms of the stable conservation of biodiversity in Korea. Therefore, based on the results of this study, it is judged that a systematic evaluation for the preservation and conservation of the habitat and vegetation management method of S. prunifolia should be conducted.
\end{abstract}

Keywords: Endangered species, Symplocos prunifolia, Syngeography, Vegetation classification

\section{Background}

Symplocos prunifolia Siebold. \& Zucc. is the only evergreen tree belonging to native Symplocaceae in Korea. This species is found only on Jeju Island in Korea. In 2010, the Korean Forest Service designated S. prunifolia as a vulnerable species (Kim et al. 2008; Korean National Arboretum 2009). However, due to the lack of information on the distribution and habitat characteristics of this species, it was not evaluated as an object of legal protection (GBIF 2020).

Studies of S. prunifolia were undertaken on several occasions during field surveys on Jeju Island and were conducted by universities and arboretums (KBIS 2020; NIBR 2020). In addition, comparative studies of warm temperate zones in Korea and the western regions of Japan found that this species is distributed in two regions that have a high plant geography connection (Kim and Itow 1996, Choi and Lee 2015). Kim and Itow (1996) defined S. prunifolia trees as well as Michelia compressa, Myrica rubra, and Marsdenia tomentosa as the phytogeographic link between the two regions. However, in a study comparing evergreen broad-leaved forest vegetation in warm temperate zones of both Korea and Japan, it is suggested that the species characterizes Japanese forests (Yoon et al. 2011). In fact, studies on evergreen broad-leaved forests in Korea, S. prunifolia, have not been recorded or suggested as a major diagnostic species of vegetation, and little is known about the habitat environment (Choi 2013). There are still insufficient data on the natural distribution of $S$. prunifolia trees in Korea, and basic studies on the natural habitat of the species have not been conducted.

As well as Korea, S. prunifolia can also be found growing in two other regions of East Asian-China and Japan. In China, S. prunifolia has been documented as an important component of mature evergreen broad-leaved forests and mixed forests in the subtropical monsoon climate region of southeastern China (Song 1988; Song and Wang 1995). However, it is not to be found growing in the semi-moist evergreen broad-leaved forest of the west which are located inland around Yunnan (SW China), but only in the eastern regions adjacent to the sea (Wang et al. 2007; Tang and Ohsawa 2009). In Japan, an island country, this species is distributed in almost all regions of the temperate climate zone. In Japan, S. prunifolia was recorded as a character species of Symploco-Shiietum cuspidatae, Cleyero-Castanopsietum cuspidatae etc., a type of evergreen broad-leaved forest found in the Kanto region of Honshu, Shikoku, Kyushu, and the Ryukyu Islands (Miyawaki et al. 1994; Hattori et al. 2012). These syntaxa is known to represent the evergreen broad-leaved forests along the Pacific Ocean coast of Japan, and S. prunifolia, Castanopsis sieboldii, Photinia glabra, and Meliosma rigida are composed of important species. These syntaxa have never been reported in Korea (Miyawaki et al. 1994).

Unlike China and Japan, the distribution of S. prunifolia is limited in Korea, and information on natural vegetation including the distribution of native places is insufficient. The lack of research on species distribution and vegetation characteristics in native habitats means that there is a lack of information on the conservation of species and sustainable management of native habitats. In particular, the limited area of distribution, small population size, and low understanding of the mechanisms for maintaining native habitats are obviously a threat to the conservation of this species in Korea. Therefore, this study aims to find out the distribution and vegetation characteristics of the $S$. prunifolia community. Based on this, we intend to prepare a 
management plan to manage and preserve the native habitat of S. prunifolia.

\section{Methods}

Investigation of native environment

To increase our understanding of the distribution of Symplocos prunifolia Siebold. \& Zucc. on Jeju Island and to confirm the characteristics of their appearance in vegetation, field surveys were conducted on all areas of Jeju Island (Fig. 1). Field surveys were conducted from March to October 2019, and vegetation, population size, and environmental factors were recorded for native habitats. In order to analyze the vegetation characteristics of native habitats, we surveyed through a $20 \mathrm{~m} \times 20 \mathrm{~m}$ $\left(400 \mathrm{~m}^{2}\right)$ quadrat considering the vegetation height and closely recording environmental factors such as GPS location information, slope aspect, rock exposure, and microtopography in the survey site.

\section{Vegetation analysis}

Vegetation surveys were made based on BraunBlanquet's phytosociological methods. All constituent species appearing in the quadrats were recorded, and the vegetation stratification structure, and the height, diameter at breast height $(\mathrm{DBH})$, crown width, vegetation coverage, and the number of each species were also recorded. Relative density, relative coverage, and relative frequency for each layer were calculated based on the number of species in the community. In addition to vegetation surveys, it was important to compare the relative abundance of each species and relative importance percentage (IP) was analyzed for each vegetation layer (Curtis and McIntosh 1951; Brower et al. 1998). The IP was calculated by calculating the mean importance percentage weighted by the vegetation layer of the individual species layer (Yi et al. 2010; Shin and Yi 2011). Diversity Index $\left(H^{\prime}\right)$, Maximum $H^{\prime}$, evenness, and dominance were calculated using DBH for tree and subtree layers, crown width for shrubs, and ground coverage for herbaceous layers to show diversity and homogeneity of constituent species for each (Shannon and Weaver 1963; Pielou 1975). Furthermore, to compare the phytosociological classification between the $S$. prunifolia vegetation surveyed in the current study and previous studies of the evergreen broad-leaved forests of Jeju Island, all vegetation data was converted to combined cover-abundance degree and analyzed (Westhoff and Maarel 1973).

For comparison with the evergreen broad-leaved forests of Jeju Island, Kim (2000)'s vegetation relevés were

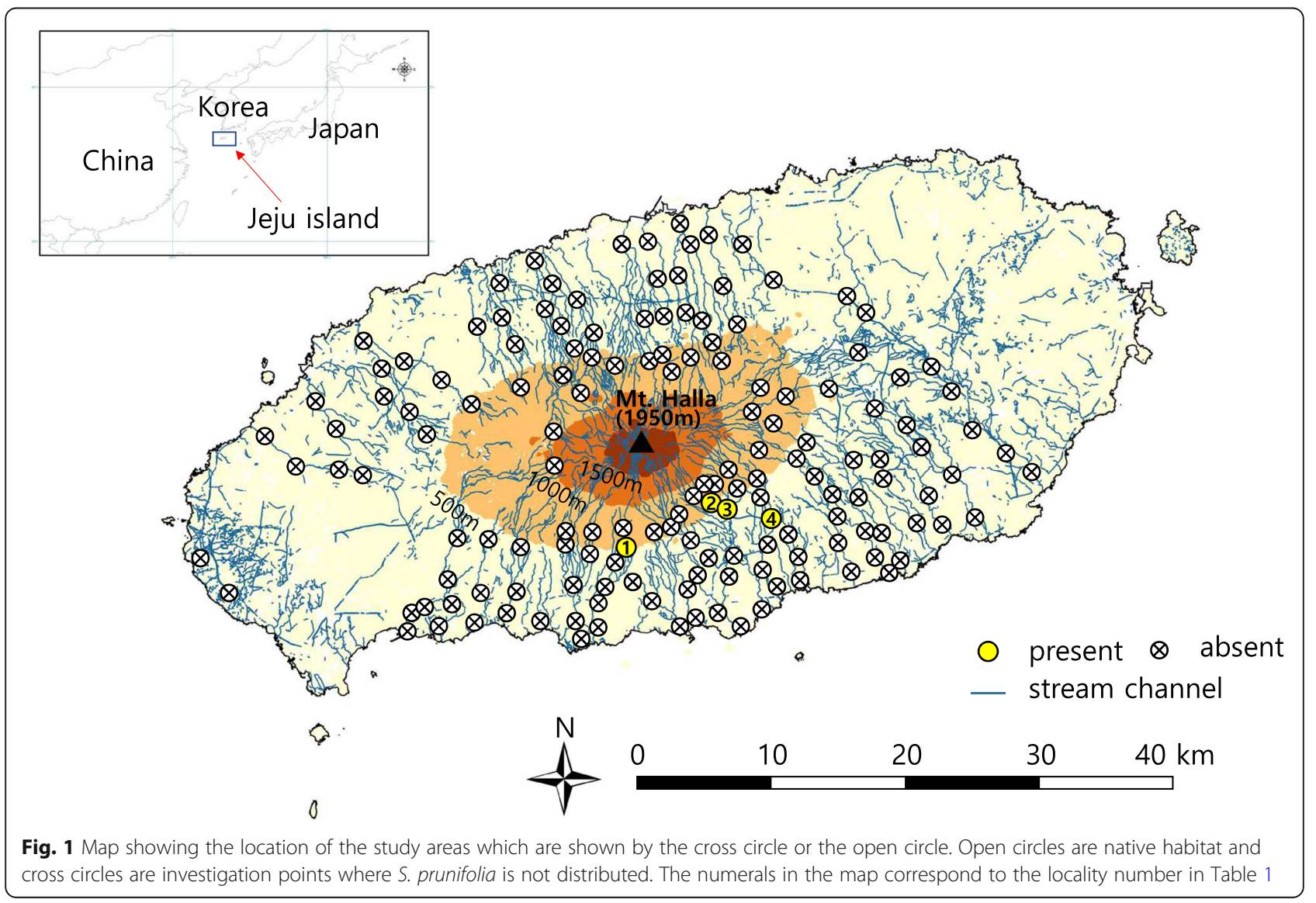


used. The vegetation data is divided into 6 sytaxa and consists of 59 relevés and 185 taxa. For qualitative and quantitative correlation and significance analysis among vegetation units, ordination and cluster analysis were performed using SYNTAX's nonmetric multidimensional scaling (NMDS) technique (Podani 2001). For ordination and cluster analysis, the NMDS (non-metric multidimentional scaling) method was analyzed in consideration of the ordinal scale characteristics of the coverage degree, and Kendal's tau and GoodmanKruskal lambda were used as coefficients. The synecological and syngeographical characteristics were discussed with respect to the relative differences derived from species composition.

Plants were identified through Lee (2003a, 2003b), Lee (1996), and KNA (2009), and when it was difficult to determine tree species, information such as photos, bark, and leaves were obtained and used to identify the tree species. The collected specimens were kept in the herbarium of Warm Temperate and Subtropical Forest Research Center. Names of syntaxon followed the International Code of Phytosociological Nomenclature (Weber et al. 2000).

\section{Results}

\section{Natural environment characteristics}

As a result of the field survey, four regions of S. prunifolia native communities were identified in Seogwipo City, which is located to the south of Mt. Halla (Table 1). These communities are in the evergreen broad-leaved forests of the warm temperate zone which are all located along the valley sides at elevations between 318 and 461 $\mathrm{m}$. Most of the native habitats of $S$. prunifolia were found on south facing slopes, but in some areas, communities existed on northwest facing slopes according to the microtopography of the location. The average rock exposure rate of these habitats is $30 \%$ (range 5 to $60 \%$ ), and the range of slope was $25^{\circ}$ to $30^{\circ}$. In terms of the structure of Jeju's streams, S. prunifolia are distributed along the floodplain areas (Fig. 2).

Located within the riparian forest, these areas are relatively wet with steep slopes and shallow soil where the possibility and frequency of disturbance remains high. In particular, the geographic location of these native habitats is prone to erosion and the deposition of sedimentation due to the constantly changing direction of the water flow. The habitat of S. prunifolia on Jeju Island shows similar characteristics to the result of being an intermediate successional sere species leading to the development of the forests into mature forests, while $S$. prunifolia are a pioneer species in Japan (Naka and Yoneda 1984; Miyawaki et al. 1994; Ito 2009). Moisture levels within the soil are constantly maintained, and the microtopography mainly consists of irregularities. The main lithosphere of native sites consists of trachybasalts (Baekrokdam trachybasalt, Boriak trachybasalt, and Siohreum trachybasalt) and trachyte (Hallasan trachyte) formed in the Quaternary period (KIGAM 2020). The soil is built up from large amounts of eroded sediment being deposited by the streams, and the humus layer was poorly developed at less than $5 \mathrm{~cm}$ in all locations. The topographical structure and soil characteristics of this environment are being constantly replenished and reformed by the constant occurrence of flooding which takes place around 10 times a year in Jeju Island (Moon et al. 2005).

\section{Native vegetation characteristics}

Vegetation structure and relative importance percentage

It has been confirmed that $S$. prunifolia trees are a rare but important constituent species of the evergreen broad-leaved forest of Jeju Island's warm temperate zone. The native vegetation structure formed four layers (canopy, subcanopy, shrubs, ground vegetation). The canopy, subcanopy, and shrub layers were greater than $30 \%$ coverage, but the herbaceous layer had a lower coverage. The average height of the trees was $14 \mathrm{~m}$, the average coverage was $75 \%$, the average height of the subtree and shrub layers were 8.8 and $3.3 \mathrm{~m}$, respectively, and the average coverage was 45.3 and $31.3 \%$, respectively. The average vegetation height of the herbaceous layer was $0.7 \mathrm{~m}$, and the average coverage was found to be $18.6 \%$ (Table 1 ). This is because the canopy layer is composed of evergreen broad-leaved tree species with high crown density, which is considered to limit vegetation development by allowing only a small amount of light to understory vegetation (Manabe et al. 2000). In particular, the evergreen broad-leaved forest limits the distribution of photophilous species and maintains a community centered on shade-tolerant species by maintaining a high crown density throughout the year, including in winter (Miura et al. 2001). Furthermore, the development of the herbaceous layer was difficult because of the widespread flooding on the slopes adjacent to the valley floor (Kang et al. 2018).

Analysis of the IP of each layer indicated that Castanopsis sieboldii was the most important component of the canopy tree layer (IP = 48.84), followed by Quercus acuta (IP = 17.79), Pinus thunbergii (IP = 12.12), and then Carpinus laxiflora (IP $=8.45$ ). In the subtree layer, Castanopsis sieboldii was the most important species (IP = 18.50), followed by Distylium racemosum (IP = 16.76), Eurya japonica (IP = 13.42), and Q. acuta (IP = 12.20). The order of the most important species in the shrub layer was E. japonica (IP = 31.18), Castanopsis sieboldii $(\mathrm{IP}=21.90)$, and Camellia japonica $(\mathrm{IP}=18.61)$, and in the herbaceous layer, the most important species were 
Table 1 General descriptions of physical character and vegetation in S. prunifolia habitats

\begin{tabular}{|c|c|c|c|c|c|}
\hline Site no. & & 1 & 2 & 3 & 4 \\
\hline Location & & Seohodong & Sanghyodong & Sanghyodong & Namwoneup \\
\hline \multirow[t]{2}{*}{ GPS* } & Latitude & $33^{\circ} 17^{\prime--" ~}$ & $33^{\circ} 19^{\prime--"}$ & $33^{\circ} 19^{\prime}-{ }^{\prime-"}$ & $33^{\circ} 19^{\prime}-{ }^{\prime \prime}$ \\
\hline & Longitude & $126^{\circ} 30^{\prime}-{ }^{\prime \prime}$ & $126^{\circ} 35^{\prime--"}$ & $126^{\circ} 35^{\prime--"}$ & $126^{\circ} 37^{\prime--"}$ \\
\hline Major direction & & SSE & NW & sSW & SSE \\
\hline Altitude (m) & & 461 & 350 & 446 & 318 \\
\hline Rock coverage (\%) & & 60 & 10 & 5 & 45 \\
\hline Slop $\left(^{\circ}\right)$ & & 25 & 30 & 25 & 25 \\
\hline Land form & & Valley & Valley & Valley & Valley \\
\hline Microtopography & & Irregularity & Irregularity & Irregularity & Irregularity \\
\hline Soil texture & & Brown forest soil & Brown forest soil & Brown forest soil & Brown forest soi \\
\hline Soil character & & Sandy loam & Silt loam & Loam & Sandy loam \\
\hline Soil moisture & & Moist & Wet & Wet & Wet \\
\hline Bedrock & & Trachyte & Trachybasalt & Trachybasalt & Trachybasalt \\
\hline Humus layer $(\mathrm{cm})$ & & $<5$ & $<5$ & $<5$ & $<5$ \\
\hline \multicolumn{6}{|c|}{ Vegetation structure } \\
\hline \multirow[t]{2}{*}{ Tree } & Height (m) & 13.0 & 13.0 & 16.0 & 14.0 \\
\hline & Coverage (\%) & 75 & 60 & 80 & 85 \\
\hline \multirow[t]{2}{*}{ Subtree } & Height (m) & 8.0 & 8.0 & 10.0 & 9.0 \\
\hline & Coverage (\%) & 55 & 55 & 45 & 30 \\
\hline \multirow[t]{2}{*}{ Shrub } & Height (m) & 3.5 & 3.0 & 3.5 & 3.0 \\
\hline & Coverage (\%) & 25 & 45 & 40 & 15 \\
\hline \multirow[t]{2}{*}{ Herb } & Height (m) & 0.6 & 0.8 & 0.9 & 0.5 \\
\hline & Coverage (\%) & 5 & 45 & 10 & 15 \\
\hline
\end{tabular}

${ }^{*}$ GPS coordinates are confidential to prevent illegal harvesting

Vaccinium japonicum (IP = 16.66), Castanopsis sieboldii $(\mathrm{IP}=16.09)$, and Camellia japonica $(\mathrm{IP}=7.38)($ Table 2).

Overall, S. prunifolia was ranked the 9th $(\mathrm{IP}=2.6$ ) when the mean importance percentage of all species across all four layers was calculated; it was ranked 5th
(IP = 4.8) in the tree layer and 6th (IP = 3.3) in the shrub layer. The quadrats $(20 \mathrm{~m} \times 20 \mathrm{~m})$ contained between 1 and 3 S. prunifolia individuals; the total coverage was not high in any of the quadrats. Although a small number of young individuals were identified in the

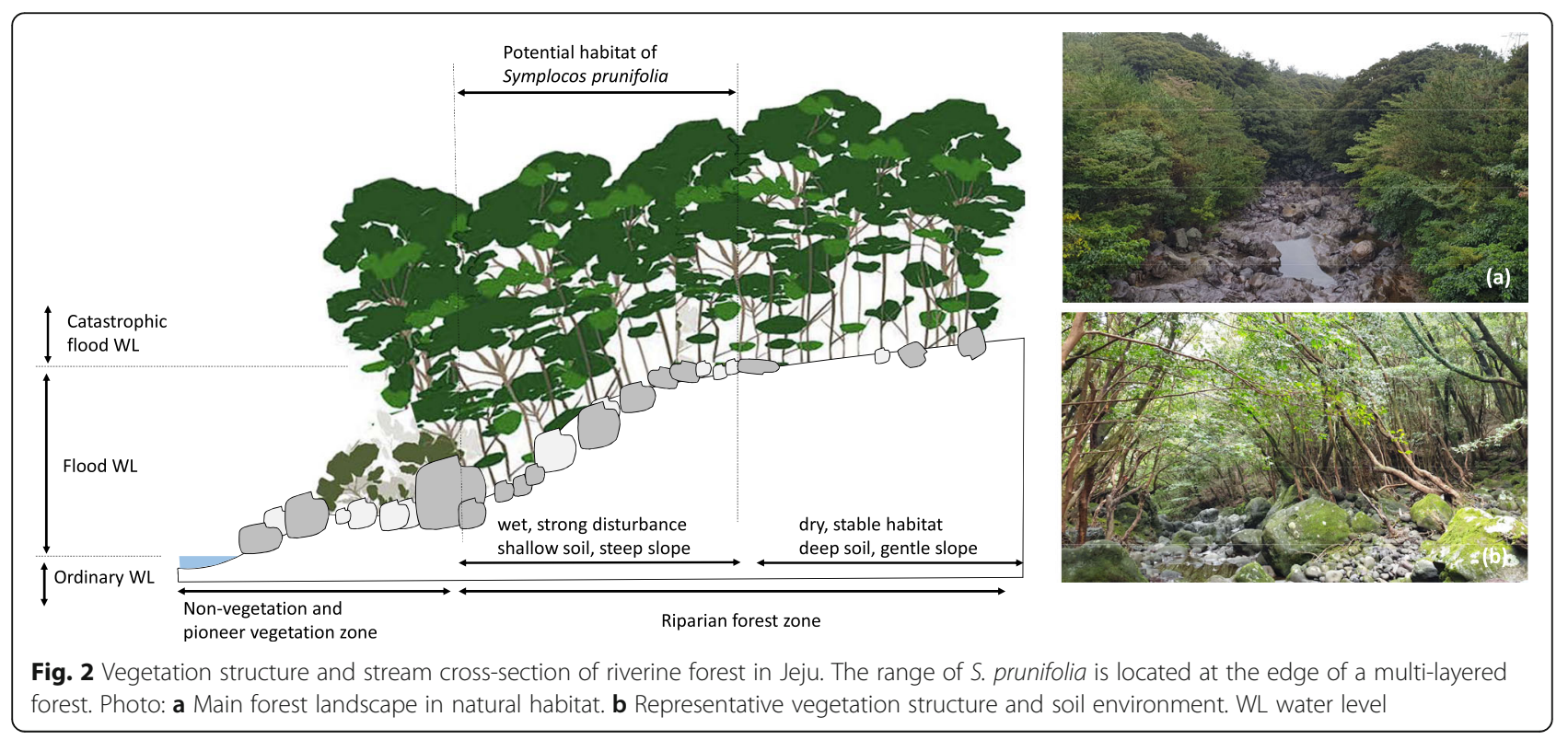


Table 2 Importance percentage (IP) and mean importance percentage (MIP) of all species in S. prunifolia community

\begin{tabular}{|c|c|c|c|c|c|}
\hline \multirow[t]{2}{*}{ Scientific name } & \multicolumn{4}{|l|}{ IP } & \multirow[t]{2}{*}{ MIP } \\
\hline & Tree & Subtree & Shrub & Herb & \\
\hline Castanopsis sieboldii (Makino) Hatus. & 48.8 & 18.5 & 21.9 & 16.1 & 31.1 \\
\hline Quercus acuta Thunb. & 17.8 & 12.2 & 5.2 & 1.2 & 11.9 \\
\hline Eurya japonica Thunb. & - & 13.4 & 31.2 & 7.2 & 11.0 \\
\hline Camellia japonica L. & - & 8.9 & 18.6 & 7.4 & 7.1 \\
\hline Distylium racemosum Siebold \& Zucc. & - & 16.8 & 5.4 & 0.9 & 6.2 \\
\hline Pinus thunbergii Parl. & 12.1 & - & - & - & 4.8 \\
\hline Carpinus laxiflora (Siebold \& Zucc.) Blume & 8.4 & 1.6 & - & 0.9 & 3.9 \\
\hline Cleyera japonica Thunb. & - & 10.2 & 2.0 & 0.8 & 3.5 \\
\hline Symplocos prunifolia Siebold \& Zucc. & 4.8 & - & 3.3 & - & 2.6 \\
\hline Styrax japonicus Siebold \& Zucc. & 2.3 & 3.4 & - & - & 1.9 \\
\hline Vaccinium japonicum Miq. & - & - & - & 16.7 & 1.7 \\
\hline Rhododendron weyrichii Maxim. & - & 3.3 & 2.5 & 1.1 & 1.6 \\
\hline Dendropanax morbiferus H.Lév. & - & 2.9 & 1.5 & 0.7 & 1.2 \\
\hline Prunus sargentii Rehder & 2.9 & - & - & - & 1.2 \\
\hline Ilex integra Thunb. & 2.9 & - & - & - & 1.1 \\
\hline Cinnamomum japonicum Siebold ex Nees & - & 1.8 & 2.3 & 0.7 & 1.1 \\
\hline Quercus salicina Blume & - & 2.3 & 1.5 & - & 1.0 \\
\hline Smilax china L. & - & 1.5 & 1.5 & 1.5 & 0.9 \\
\hline Ardisia crenata Sims & - & - & - & 5.3 & 0.5 \\
\hline Cryptomeria japonica (L.f.) D.Don & - & - & 1.8 & 1.6 & 0.5 \\
\hline Maackia fauriei (H.Lév.) Takeda & - & 1.7 & - & - & 0.5 \\
\hline Lemmaphyllum microphyllum C.Presl & - & - & - & 4.8 & 0.5 \\
\hline Sapium japonicum (Siebold \& Zucc.) Pax \& Hoffm. & - & 1.5 & - & - & 0.5 \\
\hline Deparia japonica (Thunb.) M.Kato & - & - & - & 4.1 & 0.4 \\
\hline Ardisia japonica (Thunb.) Blume & - & - & - & 4.0 & 0.4 \\
\hline Damnacanthus indicus C.F.Gaertn. & - & - & - & 4.0 & 0.4 \\
\hline Trachelospermum asiaticum (Siebold \&Zucc.) Nakai & - & - & - & 3.4 & 0.3 \\
\hline Callicarpa mollis Siebold \& Zucc. & - & - & 1.4 & - & 0.3 \\
\hline Daphniphyllum macropodum Miq. & - & - & - & 1.8 & 0.2 \\
\hline Pyrrosia lingua (Thunb.) Farw. & - & - & - & 1.8 & 0.2 \\
\hline Lepisorus thunbergianus (Kaulf.) Ching & - & - & - & 1.5 & 0.2 \\
\hline Pteridium aquilinum var. latiusculum Underw. ex Hell. & - & - & - & 1.5 & 0.2 \\
\hline Stauntonia hexaphylla (Thunb.) Decne. & - & - & - & 1.4 & 0.1 \\
\hline Dryopteris varia (L.) Kuntze & - & - & - & 1.4 & 0.1 \\
\hline Neolitsea aciculata (Blume) Koidz. & - & - & - & 1.2 & 0.1 \\
\hline Parthenocissus tricuspidata (Siebold \& Zucc.) Planch. & - & - & - & 1.1 & 0.1 \\
\hline Osmunda japonica Thunb. & - & - & - & 1.0 & 0.1 \\
\hline Ainsliaea apiculata Sch.Bip. & - & - & - & 0.9 & 0.1 \\
\hline Lindera erythrocarpa Makino & - & - & - & 0.9 & 0.1 \\
\hline Hedera rhombea (Miq.) Bean & - & - & - & 0.8 & 0.1 \\
\hline Polystichum polyblepharum var. polyblepharum Presl & - & - & - & 0.7 & 0.1 \\
\hline Clerodendrum trichotomum Thunb. & - & - & - & 0.7 & 0.1 \\
\hline Viburnum erosum Thunb. & - & - & - & 0.7 & 0.1 \\
\hline Total & 100.0 & 100.0 & 100.0 & 100.0 & 100.0 \\
\hline
\end{tabular}


upper and lower streams adjacent to the survey point, the distribution area was considered small along with the total population (Kim et al. 2008; Korean National Arboretum 2009).

Based on the results of the survey, it is estimated that the total number of $S$. prunifolia trees in the tree and subtree layers is about 30 and the number of individuals in the shrub and herb layer is about 150. Site 1 and Site 4 have relatively large populations which are distributed as mature individuals in the tree and subtree layers with relatively stable structures. In comparison to sites 1 and 4 , sites 2 and 3, it appeared that the distribution of species is found only in the shrub and herbaceous layers, and where young individuals dominate. The area and population size of each native site is about $1200 \mathrm{~m}^{2}, 36$ in site 4, about $800 \mathrm{~m}^{2}, 18$ in site 1 , about $700 \mathrm{~m}^{2}, 78$ in site 3, about $600 \mathrm{~m}^{2}, 45$ in site 2 were distributed. All individuals showed band distribution along the stream's floodplain area. Past records which were collected in the Andeok Valley area by some researchers, but this was the result of misidentification of the species, and the distribution of the species could not be confirmed at the site.

\section{Species diversity analysis}

The species diversity index was highest in the herbaceous layer (1.141), followed by the subtree layer (0.952), the tree layer $(0.548)$, and the shrub layer $(0.204)$ (Table 3$)$. The maximum species diversity calculated by the number of emergent species was highest in the herbaceous layer (1.531) followed by the subtree layer (1.176), and lowest in the tree layer (0.903). The tree layer, subtree layer, and herbaceous layer of the community species composition were all relatively stable in the range of 0.607 to 0.809 , but the shrub layer was 0.178 , which was confirmed to show severe heterogeneous species composition. When considering the ratio of the dominance of each species, the dominance by layer was 0.822 for the shrub layer, and E. japonica and Castanopsis sieboldii for the tree layer, and 0.393 for the tree layer. It was found that several taxa dominated rather than being dominated by one specific taxa. Considering the ratio of dominance of each species, it was found that the shrub layer was 0.822 , E. japonica and C. sieboldii, and the tree layer was $0.393, C$. sieboldii and Q. acuta dominated, and the subtree and herbaceous layers were
0.191 and 0.255 , respectively. Several species were mixed together without being a single species being dominate (Whittaker 1956; Sung et al. 2013).

\section{Discussion}

\section{Phytosociological comparison of the S. prunifolia} community

C. sieboldii was the dominant species in all vegetation in the S. prunifolia community; Q. acuta, D. racemosum, and E. japonica were also present. This forest belongs to the Hosto minor-Castanopsietum sieboldii, according to the characteristics of phytosociological constituent species, and shares important diagnostic species such as $Q$. acuta, Dendropanax morbiferus, Distylium racemosum, and Ainsliaea apiculata (Kim 2000). This association of an evergreen broad-leaved forest in the stream valleys of Jeju Island is known as a forest that contributes greatly to the diversity of warm temperate and subtropical organisms in Korea. The reason that the existence of $S$. prunifolia was not confirmed in previous phytosociological studies is considered to be due to the fact that the population size is very limited and so its appearance is relatively low in mature evergreen broad-leaved forests, so it was omitted from the investigation.

This vegetation found at the site is representation of the usual evergreen broad-leaved forests that are usually found along the stream valleys of Jeju Island, and it is one of the vegetation units that contributes greatly to the diversity of species in the warm temperate and subtropical zones of Korea. In the previously reported vegetation studies, it was judged that the S. prunifolia did not appear as a constituent species, the population size was insignificant, and so it was not included in the vegetation survey of typical evergreen broad-leaved forests (Oh 1995; Kim 2000; Choi 2013; Yoon et al. 2014).

As a result of ordination analysis, the species characteristics of the S. pruniolia community were also identified as a type of Castanopsis-dominated community of Jeju Island, which showed high similarity with the Hosto minor-Castanopsietum sieboldii (Fig. 3). The Hosto minor-Castanopsietum sieboldii is reported to be one of the unique evergreen broad-leaved forests of Jeju Island and is distinct from vegetation associated with the species in Japan and China (Choi 2013). In the cluster analysis results, a small group was formed that was distinguished from the existing Jeju Island evergreen broad-

Table 3 Species diversity indices for all species in S. prunifolia community

\begin{tabular}{|c|c|c|c|c|c|}
\hline Layer & No. of species & $\mathrm{H}^{\prime}$ (Species diversity) & $H^{\prime} \max$ & $J^{\prime}$ (evenness) & $\mathrm{D}$ (dominance) \\
\hline Tree & 8 & 0.548 & 0.903 & 0.607 & 0.393 \\
\hline Subtree & 15 & 0.952 & 1.176 & 0.809 & 0.191 \\
\hline Shrub & 14 & 0.204 & 1.146 & 0.178 & 0.822 \\
\hline Herb & 34 & 1.141 & 1.531 & 0.745 & 0.255 \\
\hline
\end{tabular}




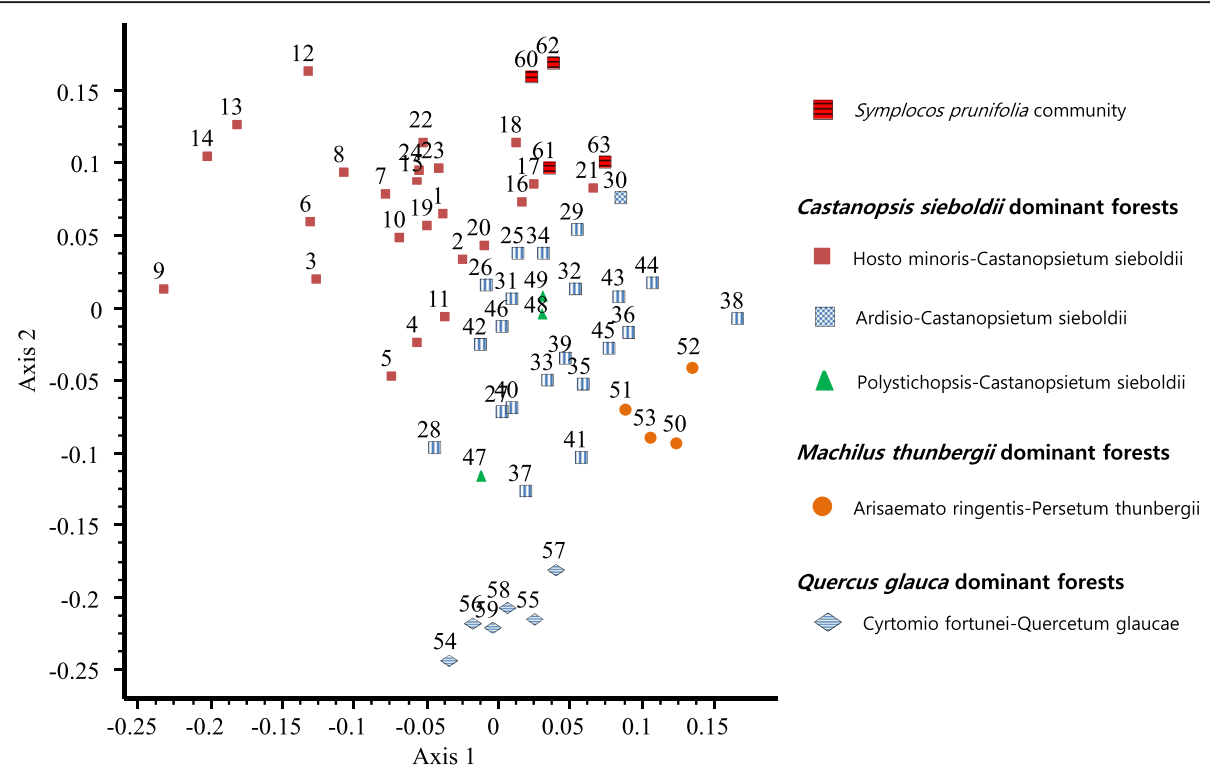

Fig. 3 NMDS ordination of warm temperate evergreen broad-leaved forests and S. prunifolia community in Jeju. The data sources for warm temperate evergreen broad-leaved forest of Jeju are Kim (2000). (no. 1 24: Hosto minoris-Castanopsietum sieboldii Kim, Hukusima et Hoshino 1994, no. 25 46: Ardisio-Castanopsietum sieboldii Suz..-Tok. 1952, no. 47 49: Polystichopsis-Castanopsietum sieboldii Miyawaki et al. 1971 , no. 50 53: Arisaemato ringensis-Perseetum thunbergii Miyawaki et al. 1971, no. 54 59: Cyrtomio fortunei-Quercetum glaucae Kim, Hukusima et Hoshino, 1994, no. 60 63: S. prunifolia community)

leaved forest, which was a result of differences in constituent species such as Vaccinium japonicum, Carpinus laxiflora, Callicarpa mollis, Deparia japonica, and Cryptomeria japonica (Fig. 4). However, the difference between these species is not too different to the extent that the association is newly defined, and most were widely distributed species, cold-temperate species, pioneer species, and accidental species.

Therefore, S. prunifolia is a character species and an important diagnostic species in such forests as Hosto minor-Castanopsietum sieboldii in Korea, Pinus massoniana-Schima superba community in China Symploco glaucae-Castanopsietum sieboldii, Symploco glaucae-Castanopsietum sieboldii, and CleyeroCastanopsis cuspidatae in Japan (Miyawaki et al. 1994; Wang et al. 2007). The distribution of these syntaxa is considered to be closely related to the influence of the Oceanic climate and the Kuroshio warm current $\left(111^{\circ} 01^{\prime} \mathrm{E}-139^{\circ} 54^{\prime} \mathrm{E}, 22^{\circ} 20^{\prime} \mathrm{N}-36^{\circ} 00^{\prime} \mathrm{N}\right)$ (Fig. 5). The Kuroshio warm current, which existed even during the ice age in East Asia, has maintained evergreen broadleaved forests in the Kagoshima region of southern Japan, making it the longest documented warm temperate vegetation history in all of East Asia (Tsukada 1985; Miyoshi et al. 1999). After the ice age, evergreen broadleaved forests in East Asia gradually expanded to the north due to continuous temperature rises and sea level expansion (Zheng et al. 2014). The expansion of the sphere of influence of the Kuroshio current is deeply linked to the movement of these species (Miyawaki et al. 1994; Tang 2015). The expansion of Korea's evergreen broad-leaved forest is also highly linked to the expansion of species centered around these regions. In particular, the expansion of warm maritime currents in these regions is considered as an important factor which has had a significate influence on the expansion of vegetation. This is reflected in part by the lack of migration inland of Korea's evergreen broad-leaved forests and why they are located only in coastal areas (Yim and Kira 1975; Choi 2013). Among them, the distribution of $S$. prunifolia, particularly in the maritime climate region, is judged to be determined by the expansion of the Kuroshio warm current and its sphere of influence (Kawahata and Ohshima 2004).

The evergreen broad-leaved forests of Jeju Island have a long history in the warm temperate zone of Korea. As mentioned above, it is the first region that the species settled after the ice age in East Asia. As a result, it shows the largest diversity of evergreen broad-leaved trees in the warm temperate zone of Korea, and why the species is only found on Jeju Island. However, the continental climate still has an indirect influence on Jeju Island. This is evident in the characteristics of the intermediate climate zone and a marine climate, as only partial vegetation is formed (Kim 1992; Eom 2019). Among these, $S$. prunifolia and some evergreen broad-leaved tree species 


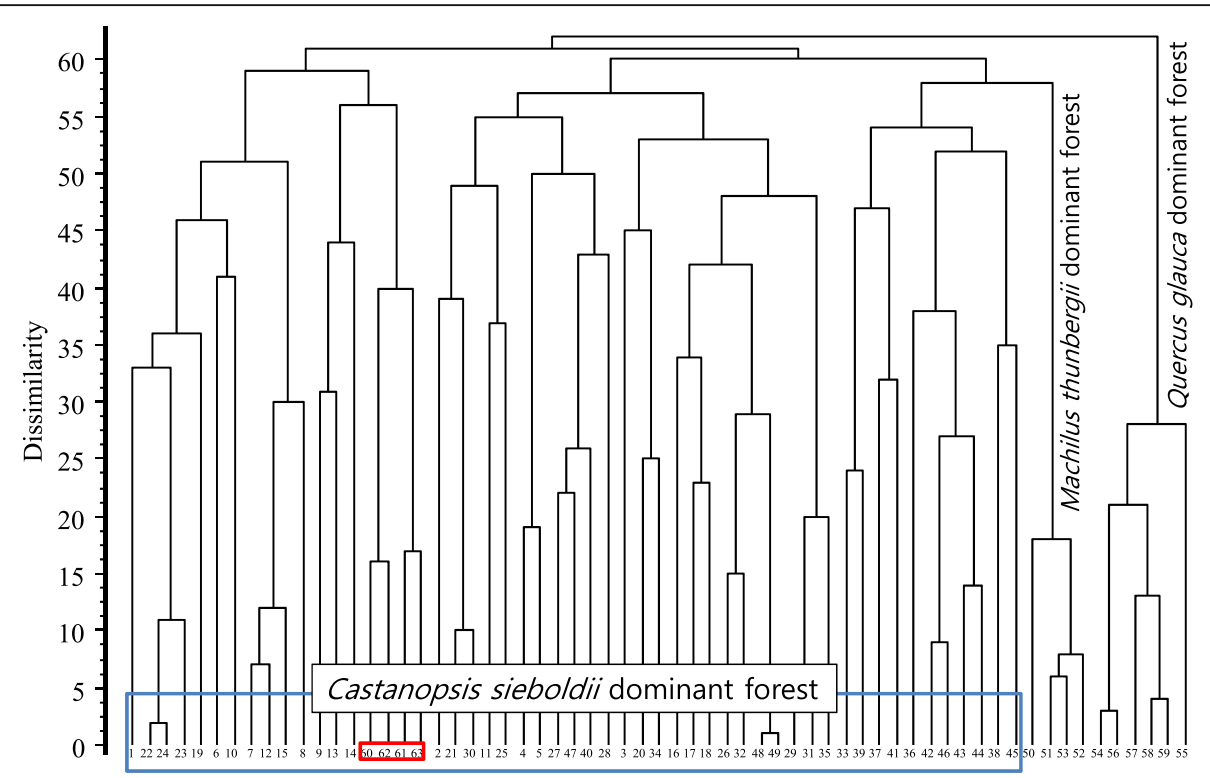

Fig. 4 Dendrogram showing floristic similarity. NMDS clustering of evergreen broad-leaved forests and S. prunifolia community in Jeju. Numbers are same as Fig. 3

are thought to be distribution-dependent on the forests adjacent to the stream with minimal continental climate (Kim 2000).

Species, including S. prunifolia, have a relatively short migration history in Korea when compared to Chinese and Japanese vegetation, which are at the centers of warm temperate and subtropical forest regions of East Asia, and where diversity of species is greater (Chinzei et al. 1987; Chung 2007). Nevertheless, the S. prunifolia community of Jeju Island is one of the northernmost distribution areas in Northeast Asia, and it can be considered as a significant indicator of the change in forest vegetation expansion in warm temperate zones (Harrison et al. 2001, Corlett 2009) (Fig. 5).

However, it has been confirmed that species of S. prunifolia on Jeju Island are vulnerable to various threats. As revealed in the results of this study, there are only 4 native areas which sustain the 180 individual plants. Fortunately, two of these native sites form a relatively stable population structure, but others do not. Among the native vegetation, it appears in fewer numbers than other species in the tree layer (Castanopsis sieboldii, Quercus

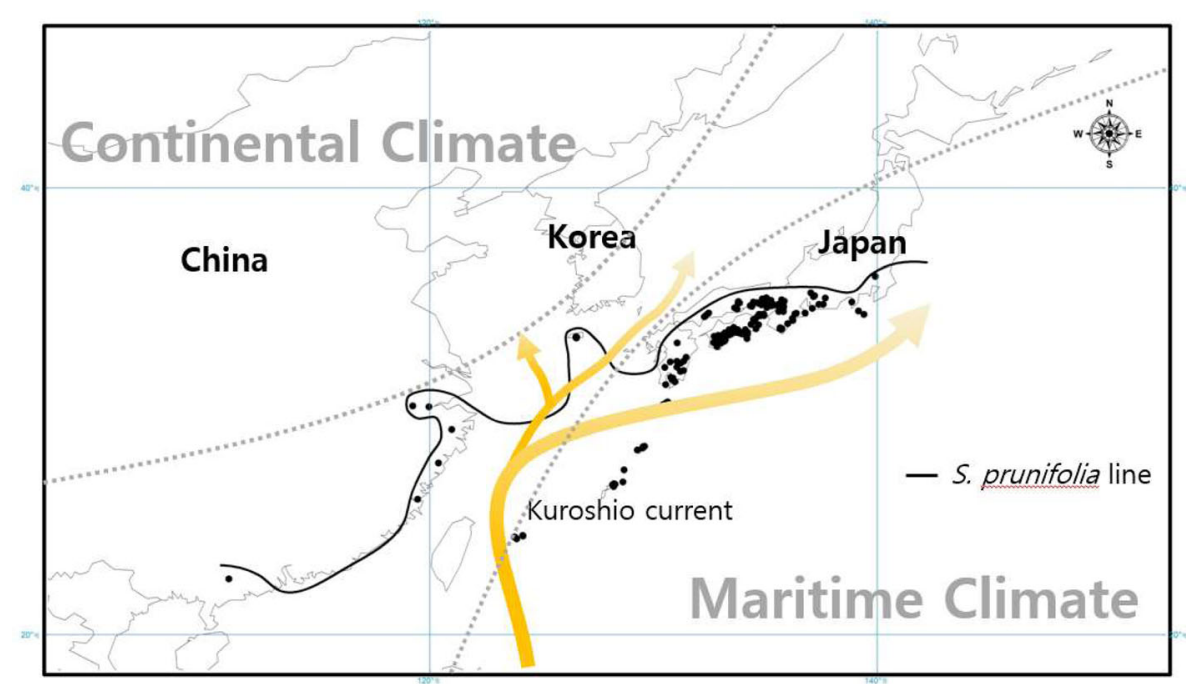

Fig. 5 Phytogeography of S. prunifolia and high correlation with Kuroshio current in East Asia. The data sources for phytogeography of S. prunifolia community in East Asia are GBIF (2020), Miyawaki et al. (1994), Tang (2015) and this study 
acuta, Pinus thunbergii, Carpinus laxiflora, etc.), and its growth is relatively slow, which is disadvantageous to competition (Hong et al. 2019). In particular, even in the vegetation succession process, it is difficult to secure the stability of the population because S. prunifolia seedlings have relatively weak shade tolerance in the evergreen broad-leaved forest at the late seral stage have poor regeneration (Oh and Choi 1993). Furthermore, the lowfruiting and irregular rates of the observed S. prunifolia in the field make it difficult to ascertain which physiological and ecological factors this phenomenon is due to, but it is considered to act as a negative factor for maintaining a healthy community and the spread of species.

In particular, it is feared that excessive development of Jeju Island's streams will reduce the area of Jeju's riverine forest, which is the only native habitat of $S$. prunifolia, which will in turn will lead to a decline in species numbers. It is feared that excessive development of Jeju Island's streams will also reduce the area of Jeju's riverine forest, leading to a loss of native habitat of $S$. prunifolia and causing a decline of both habitat and species (Song et al. 2019). Therefore, in terms of conservation of national biodiversity, there is a need for more extensive ecological studies on species and to prepare a conservation management plan for these native sites.

\section{Conclusion}

S. prunifolia is found along the natural streams of Jeju Island, where there is little anthropogenic influence, and where the streams cause soil disturbance through the process of erosion and deposition of sediments. Currently, the area of the site where the native growth of $S$. prunifolia is confirmed at about $3300 \mathrm{~m}^{2}$, which is relatively small, and is home to 180 individual plants which places it among other rare species in Korea. The vegetation in which they appear has been identified as one of Jeju's unique vegetation types the Hosto minorisCastanopsietum sieboldii. This syntaxa contains a large number of the endemic species of vegetation along with the warm temperate species which represent the warm temperate riverine forest of Jeju Island. It is accepted that S. prunifolia is distributed as a constituent species at the edge of this vegetation. It appears in the canopy layer according to its location and was a major constituent of evergreen broad-leaved forests, but the frequency and coverage of the species were still not high. Unfortunately, due to its specific characteristics of weak shade tolerance, low-fruiting rate, and irregular alternate fruit bearing cycles, along with external factors such as a reduction of potential habitats and the natural processes of soils disturbance, it continues to demonstrate rare distribution characteristics on Jeju Island.
It is thought that S. prunifolia is in the process of adapting and migrating to new areas on Jeju Island, which is located along the transition point between the continental and marine climates of East Asia. It is a species that is thought to have difficulty settling in Korea's evergreen broad-leaved forest. Furthermore, it is a significant marker and evidence that the number of marine species, including S. prunifolia, are gradually appearing in the country. The protection of this species is urgent given its circumstances of limited habitats. In the future, it is unclear whether this species will gradually see an increase in its population and an expansion of its native habitats given the difficulties many species face with climate change. What is clear, however, is that the survival and health of the current native habitat is paramount to the future survival of the species. In addition, the stable preservation of this species is important in terms of biodiversity of plant life in Korea.

In conclusion, there is an urgently need to prepare a conservation management plan for the protection of this species and its native habitat areas, as well as to reevaluate the species' conservation level. Active protection efforts are urgently required with continuous monitoring of mature individuals, along with additional studies on additional native sites, and potential distribution sites are also required.

\section{Abbreviations \\ GBIF: Global Biodiversity Information Facility; KBIS: Korea Biodiversity Information System; KIGAM: Korea Institute of Geoscience and Mineral Resources; NIBR: National Institute of Biological Resources}

\section{Acknowledgements}

Not applicable.

\section{Authors' contributions}

YJK, KMS, and BKC wrote the manuscript; KMS and BKC made the figures; YJK and KMS made the tables; BKC, YOS, and HSC modified the language; YJK, EYY, and BKC collected the literature; KMS and BKC provided the ideas. All the authors agreed on the contents of the paper and post no conflicting interest. The authors read and approved the final manuscript.

\section{Funding}

Not applicable.

\section{Availability of data and materials}

The datasets used and/or analyzed during the current study are available from the corresponding author (Dr. Byoung-Ki Choi, vegetation01@korea.kr) on reasonable request.

\section{Ethics approval and consent to participate} Not applicable.

\section{Consent for publication}

Not applicable.

\section{Competing interests}

The authors declare that they have no competing interests. 
Received: 27 July 2020 Accepted: 11 November 2020

Published online: 09 December 2020

\section{References}

Brower JE, Zar JH, Ende CN. Field and laboratory method for general ecology. 4th ed. Boston: WCB McGraw-Hill; 1998.

Chinzei K, Fujioka K, Kitazato H, Koizumi I, Oba T, Oda M, et al. Postglacial environmental change of the Pacific Ocean off the coastal of Central Japan. Mar Micropaleo. 1987;11:273-91.

Choi BK, Syntaxonomy and syngeography of warm-temperate evergreen broadleaved forests in Korea. Daegu: Keimyung Univ. PhD Thesis; 2013.

Choi BK, Lee CB. A study on the synecological values of the Torreya nucifera forest (natural monument no. 374) at Pyeongdae-ri in Jeju Island. J Korean Inst Trad Land Arch. 2015;33(4):87-98.

Chung $\mathrm{CH}$. Vegetation response to climate change on Jeju Island, South Korea, during the last deglaciation based on pollen record. Geosci J. 2007;11:14755 .

Corlett RT. Seed dispersal distances and plant migration potential in tropical East Asia. Biotro. 2009;41:592-8.

Curtis JT, McIntosh RP. An upland forest continuum in the prairie-forest border region of Wisconsin. Ecology. 1951;32:476-96.

Eom BC, Climatically potential natural vegetation and phytoclimatic map of Korea. Daegu. Keimyung Univ. PhD Thesis; 2019.

GBIF (2020) Global biodiversity information facility. URL: https://www.gbif.org/.

Harrison SP, Yu G, Takahara H, Prentice IC. Diversity of temperate plants in East Asia. Nature. 2001:413:129-30

Hattori T, Minamiyama N, Kuroda A. Phytosociological system of the natural lucidophyllous forests in Japan. Human Nat. 2012;23:1-29.

Hong YS, Kim EJ, Lee EP, Lee SY, Cho KT, Lee YK, et al. Characteristics of vegetation succession on the Pinus thunbergii forests in warm temperate regions, Jeju Island. South Korea J Ecol Environ. 2019;43(4):438-53.

Ito HK. A comparison of seedling emergence and survival between Quercus glauca and Symplocos prunifolia. J For Res. 2009;14:245-50.

Kang MS, Lee YJ, Park CY, Yoo CS. A new classification rule of hydrological soil groups of Jeju Island: application to representative basins and evaluation of previous studies. J Kor Wat Res Ass. 2018;51:1261-71.

Kawahata $\mathrm{H}$, Ohshima $\mathrm{H}$. Vegetation and environmental record in the northern East China Sea during the late Pleistocene. Glob Planet. 2004:41:251-73.

KBIS. Korea Biodiversity Information System. URL: https://www.nature.go.kr/. 2020

KIGAM. Korea Institute of Geoscience and Mineral Resources. URL: https://www. kigam.re.kr/. 2020

Kim CS, Koh JG, Moon MO, Song GP, Kim SY, Kim J, et al. Rare plants of Jeju Island. Kor For Res Ins: Seoul; 2008.

Kim JW. Vegetation of Northeast Asia: on the syntaxonomy and syngeography of the oak and beech forests. Vienna: University of Vienna. PhD Thesis; 1992.

Kim MH. Phytosociological study on the vegetation of Cheju Island, Korea. Jeju: Jeju Univ. PhD Thesis; 2000.

Kim MH, Itow S. Distribution of evergreen broad-leaved plants in satellite islands of Korea and Western Kyushu, Japan (1) distribution of tree species and factors of distribution. J Bas Sci Cheju Univ. 1996;9:107-20.

KNA (Korea National Arboretum). Rare Plants Data Book in Korea. Pocheon: Kor Nat Arb; 2009.

Lee CB. Coloured flora of Korea I volumes. Hyangmunsa: Seoul; 2003a.

Lee CB. Coloured flora of Korea II volumes. Hyangmunsa: Seoul; $2003 \mathrm{~b}$.

Lee WT. Lineamenta Flora Koreae. Seoul: Academy Press; 1996.

Manabe T, Nishimura N, Miura M, Yamamoto S. Population structure and spatial patterns for trees in a temperate old-growth evergreen broad-leaved forest in Japan. Plant Ecol. 2000;151:181-97.

Miura M, Manabe T, Nishimura N, Yamamoto S. Forest canopy and community dynamics in a temperate old-growth evergreen broad-leaved forest, SouthWestern Japan: a 7-year study of a 4-ha plot. J Ecol. 2001;89:841-9.

Miyawaki A, Okuda S, Fujiwara R. Handbook of Japanese vegetation. Shibundo Pub: Tokyo; 1994

Miyoshi N, Fujiki T, Morita Y. Palynology of a 250-m core from Lake Biwa: a 430,000 -year record of glacial-interglacial vegetation change in Japan. $R$ Palaeo and Paly. 1999;104:267-83.

Moon DC, Yang SK, Koh GW, Park WB. Estimation of baseflow discharge through several streams in Jeju Island. Korea J Envir Sci. 2005;14:405-12.

Naka K, Yoneda T. Community dynamics of evergreen broadleaf forests in southwestern Japan. III. Revegetation in gaps in an evergreen oak forest. Bot Mag Tok. 1984;97:275-86.
NIBR. National Institute of Biological Resources. URL: https://www.nibr.go.kr/; 2020.

Oh JG. Comparative studies on evergreen broad-leaved forests of Dadohae National Marine Park in Korea and Nagasakigen in Japan. Mokpo: Mokpo Univ. PhD Thesis; 1995.

Oh KK, Choi SH. Vegetation structure and successional sere of warm temperate evergreen forest region. Korea Kor J Ecol. 1993;16(4):459-76.

Pielou EC. Ecological diversity. New York: John Wiley and Sons; 1975.

Podani J. SYNTAX 2000: computer program for data analysis in ecology and systematics. Budapest: Scientia Pub; 2001.

Shannon CE, Weaver W. The mathematical theory of communication. Urbana \& Illinois: Univ. Illinois press; 1963.

Shin HT, Yi MH. The relationship between soil seed bank and ground layer of actual vegetation in Korea. J Environ Sci. 2011;20:127-35.

Song KM. An analysis of a 100-years-old map of the heritage trees in Jeju Island. J Korean Inst Trad Land Arch. 2019.37(2):20 29.

Song YC. The essential characteristics and main types of the broad-leaved evergreen forest in China. Phytoco. 1988;16:105-23.

Song YC, Wang XR. Vegetation and flora of Tiantong National Forest Park, Zheijiang Province China. Shanghai: Shang Sci Tech Liter Press; 1995.

Sung JW, Yi MH, Yoon JW, Kim GS, Shin HT, Kim YS. Growth environment and vegetation structure of native habitat of Corydalis cornupetala. Kor J Environ ECo. 2013;27:271-9.

Tang CQ. The subtropical vegetation of southwestern China. Heidelberg: Springer; 2015.

Tang CQ, Ohsawa M. Ecology of subtropical evergreen broad-leaved forests of Yunnan, southwestern China as compared to those of southwestern Japan. J Plant Res. 2009;122:335-50.

Tsukada M. Map of vegetation during the last glacial maximum in Japan. Quat Res. 1985;23:369-81.

Wang XH, Kent M, Fang XF. Evergreen broad-leaved forest in eastern China: its ecology and conservation and the importance of resprouting in forest restoration. For Ecol Manag. 2007;245:76-87.

Weber HE, Moravec J, Theurillat JP. International code of phytosociological nomenclature. $3^{\text {rd }}$ edition. J Veg Sci. 2000;11:739-68.

Westhoff V, Maarel EV. The Braun-Blanquet approach, in RH Whittaker (Eds.) ordination and classification of communities. The Hague: Dr. Junk, W. Pub; 1973.

Whittaker RH. Vegetation of the Great Smoky Mountains. Ecol Monogr. 1956;26: $1-80$.

Yi MH, Kim YS, Kim DG, Park SG, Shin HT. The relationship between soil seed bank and actual vegetation. Kor J Environ Ecol. 2010;24:638-47.

Yim YJ, Kira T. Distribution of forest vegetation and climate in the Korean peninsula: I. distribution of some indices of thermal climate. Ecol Soc Jap. 1975;25(2):77-88

Yoon JH, Hukusima T, Kim MH, Yoshikawa M. The comparative studies on the distribution and species composition of forest community in Korea and Japan around the East Sea. Kor J Environ Ecol. 2011;25:327-57.

Yoon JW, Yi MH, Kim YS. Growth environment and vegetation structure of native habitats of Wikstroemia ganpi (Sieb. Et Zucc.) maxim. Kor J Environ Ecol. 2014; 28:331-41.

Zheng Z, Wei JH, Huang KY, Xu CH, Lu HY, Tarasov P, et al. East Asian pollen database: modern pollen distribution and its quantitative relationship with vegetation and climate. J Biogeogr. 2014;41:1819-32.

\section{Publisher's Note}

Springer Nature remains neutral with regard to jurisdictional claims in published maps and institutional affiliations. 